Soegiharto, et al/Jurnal Ekonomi Syariah Teori dan Terapan Vol. 6 No. 1 Januari 2019: 42-58; PERBANDINGAN CORPORATE SOCIAL PERFORMANCE PADA BANK UMUM SYARIAH DI INDONESIA PERIODE 2013-2016 (STUDI PADA BSM, BMI, BRIS, BNIS, BMS, BVS, BCAS, BPS, BSB, BJBS, MS, DAN BAS)

\title{
PERBANDINGAN CORPORATE SOCIAL PERFORMANCE PADA BANK UMUM SYARIAH DI INDONESIA PERIODE 2013-2016
}

(STUDI PADA BSM, BMI, BRIS, BNIS, BMS, BVS, BCAS, BPS, BSB, BJBS, MS, DAN BAS)

\section{Renata Amelia Soegiharto}

Departemen Ekonomi Syariah-Fakultas Ekonomi dan Bisnis-Universitas Airlangga Email: renata.amelia-13@feb.unair.ac.id

\author{
Atina Shofawati \\ Departemen Ekonomi Syariah-Fakultas Ekonomi dan Bisnis-Universitas Airlangga \\ Email: atina-o@feb.unair.ac.id
}

\begin{abstract}
:
This research aims to discover whether there are differences in the social performance of the Islamic Banks period for the year of 2013 to 2016. The method used in this research is quantitative method with purposive sampling. The study sample was twelve Islamic Banks in Indonesia. Analysis of test of difference used ANOVA and Kruskal-Wallis tests. The ratio assessment of social performance was analyzed using fifteen variables; those are MMR, AR, KPJP, PFA, QR, ZR, RFS, CSR, KSM, KM, KI, KPW, KPP, PKSR, and R\&D. The data used is secondary data gathered financial report in period 2013-2016. Comparative analysis of social performance ratios showed the differences in the social performance of Islamic banks, except in the ratio of CSR that showed no significant difference.
\end{abstract}

Keywords: Social Performance, Islamic Banks, Comparative Analysis, CSP.

I.

PENDAHULUAN

Industri perbankan syariah

mempunyai peranan penting dalam perekonomian. Peran perbankan syariah dalam aktivitas ekonomi berbeda dengan perbankan konvensional. Perbedaan yang paling mendasar adalah pada prinsip transaksi keuangan maupun operasionalnya. Perbankan syariah dengan jelas menerapkan syariat Islam, salah satu prinsip dalam operasional perbankan syariah adalah penerapan profit and loss sharing. Prinsip ini tidak berlaku di perbankan konvensional yang menerapkan sistem bunga. Keadilan akan tercipta apabila menerapkan sistem bagi hasil dalam memberikan keuntungan bagi para nasabah dan pihak bank sendiri.

Sistem bagi hasil pada perbankan syariah yaitu sistem yang tidak mengandung unsur riba dalam memberiimbal hasil. Menurut istilah teknis riba berarti pengambilan tambahan dari harta pokok atau modal secara batil (Antonio, 2001: 37). Oleh karena itu riba sangat jelas dilarang dalam Islam karena hanya menguntungkan satu pihak saja dan merugikan pihak lainnya. Larangan riba atau pengambilan harta secara batil terdapat dalam firman Allah dalam firman-Nya Surat An-Nisaa' ayat 29, yang artinya: "Hai orang-orang yang beriman, janganlah kamu saling memakan harta sesamamu dengan jalan yang batil, kecuali dengan jalan perniagaan yang Berlaku dengan suka sama-suka di antara kamu. Janganlah kamu membunuh dirimu. Sesungguhnya Allah adalah Maha Penyayang kepadamu" (Depag, 2002).

1) Jurnal ini merupakan bagian dari skripsi Renata Amelia Soegiharto, NIM: 041311433009 , yang diuji pada tanggal 19 Juli 2018. 
Soegiharto, et al/Jurnal Ekonomi Syariah Teori dan Terapan Vol. 6 No. 1 Januari 2019: 42-58; PERBANDINGAN CORPORATE SOCIAL PERFORMANCE PADA BANK UMUM SYARIAH DI INDONESIA PERIODE 2013-2016 (STUDI PADA BSM, BMI, BRIS, BNIS, BMS, BVS, BCAS, BPS, BSB, BJBS, MS, DAN BAS)

Berdasarkan UU No. 21 Tahun 2008 pasal 4 Tentang Perbankan Syariah, bahwa selain berkewajiban menjalankan fungsi menghimpun dan menyalurkan dana masyarakat, bank syariah dan UUS dapat menjalankan fungsi sosial dalam bentuk lembaga baitul mal, yaitu menerima dana yang berasal dari zakat, infak, sedekah, hibah atau dana sosial lainnya dan menyalurkannya pada organisasi pengelola zakat. Fungsi sosial tersebut yang menjadi pembeda antara bank syariah dengan bank konvensional karena mencerminkan salah satu prinsip ekonomi Islam yaitu distribusi kekayaan. Selain itu bank syariah dan UUS juga dapat menghimpun dana sosial yang berasal dari wakaf vang dan menyalurkannya kepada pengelola wakaf (nazhir) sesuai dengan kehendak pemberi wakaf (wakif).

Bank syariah merupakan lembaga bisnis kevangan yang melaksanakan kegiatan usahanya berdasarkan prinsip dasar dalam ekonomi Islam. Tujuan ekonomi Islam pada bank syariah tidak hanya berfokus pada tujuan komersial saja yaitu mengutamakan pencapaian keuntungan semata (Profit-Oriented), tetapi juga mempertimbangkan perannya dalam memberikan kesejahteraan kepada masyarakat. Peran tersebut merupakan peran bank syariah dalam melaksanakan fungsi sosialnya. Fungsi sosial tersebut paling nampak saat diwujudkan melalui aktivitas penghimpunan dan penyaluran zakat, infaq, sadaqah dan waqaf (ZISWAF).
Melalui fungsi sosial ini diharapkan akan memperlancar alokasi dan distribusi dana sosial yang dibutuhkan oleh masyarakat. Di Indonesia, regulasi mengenai bank syariah dibagi menurut jenisnya terdiri atas Bank Umum Syariah, Unit Usaha Syariah dan Bank Pembiayaan Syariah (BPRS).

Pada dasarnya kinerja dalam bank syariah sesuai dengan fungsinya terbagi menjadi dua yaitu fungsi bisnis (tijarah) dan fungi sosial (tabarru'). Fungsi bisnis maupun fungsi sosial memerlukan pengukuran kinerja untuk melihat seberapa besar bank syariah menjaga komitmen dalam menjalankan kedua fungsi tersebut. Pengukuran tersebut memberikan gambaran atas kelebihan dan kekurangan yang terdapat dalam kinerja fungsi bisnis dan fungsi sosial. Pengukuran kinerja bank sangat penting untuk masa depan bank, yaitu salah satunya alat untuk menentukan kebijakan yang akan diambil untuk masa depan bank dengan cara melihat kinerja dari masa lalu.

$$
\text { Menurut Al-Jawziyyah, (1995); }
$$
Rahman dan Goddard, (1998), kinerja sosial dalam Islam merupakan suatu kewajiban, karena dalam Islam tidak melakukan aktivitas bisnis hanya untuk kepuasan nafsu dan materi semata melainkan hal yang lebih penting adalah seharusnya dilaukan untuk memenuhi perintah agama dan mengamankan kebutuhan sosial. Fungsi sosial diteliti untuk mengetahui seberapa besar peran bank syariah dalam menyejahterakan masyarakat melalui fungsi sosialnya, baik 
Soegiharto, et al/Jurnal Ekonomi Syariah Teori dan Terapan Vol. 6 No. 1 Januari 2019: 42-58; PERBANDINGAN CORPORATE SOCIAL PERFORMANCE PADA BANK UMUM SYARIAH DI INDONESIA PERIODE 2013-2016 (STUDI PADA BSM, BMI, BRIS, BNIS, BMS, BVS, BCAS, BPS, BSB, BJBS, MS, DAN BAS)

masyarakat umum ataupun nasabah bank itu sendiri yang sesuai dengan peraturan yang berlaku dalam perbankan syariah. Selain itu, fungsi sosial bank syariah merupakan inti dari perekonomian Islam yang mengajarkan manusia atas keseimbangan antara kehidupan dunia dan sosial dalam mencapai falah sebagai tujuan hidup.

Permasalahan dalam penelitian ini yaitu sejauh mana pemenuhan tanggung jawab sosial tersebut telah diwujudkan oleh bank syariah. Apakah fungsi bisnis dan fungsi sosial ini diajalankan secarara seimbang atau lebih cenderung fokus untuk mengembangkan fungsi bisnisnya saja sehingga fungsi sosial terabaikan. Penelitian kinerja fungsi sosial juga untuk mengetahui apakah terdapat perbedaan kinerja kinerja fungsi sosial dilihat dari status bank. Pengetahuan mengenai kekuatan bank, dapat dimanfaatkan untuk pembangunan kinerja bank selanjutnya. Kelemahan dari kinerja tersebut dapat dijadikan evaluasi dari kinerja perbankan di masa yang akan datang. Dengan penjelasan tersebut, masalah kinerja fungsi sosial antara dua bank tersebut masih perlu diteliti lebih lanjut (Fadli, 2012).

Oleh karena itu, penelitian ini bertujuan untuk melakukan perbandingan perbedaan kinerja sosial yang diukur dengan 5 teori yaitu: Kontribusi Pembangunan Ekonomi (KPE); Kontribusi Kepada Masyarakat (KKM); Kontribusi Untuk Stakeholder (KUS); Peningkatan Kapasitas SDI dan Riset (PKSR); serta Distribusi Pembangunan Ekonomi (DPE), yang didalamnya terdapat 15 rasio antara lain Intensitas Pembiayaan Profit Sharing (MMR), Intensitas Fungsi Agency (AR), Kontribusi Pembangunan Jangka Panjang (KPJP), Rasio Pendalaman Fungsi Agency (PFA), Rasio Pembiayaan Qardh (QR), Rasio Kinerja Zakat (ZR), Rasio Pelaksanaan Fungsi Sosial (RFS), Rasio Pelaksanaan Fungsi Edukasi (CSR), Rasio Kontribusi Kesejahteraan Sahibul Maal (KSM), Rasio Alokasi Kesejahteraan Mudharib (KM), Rasio Kontribusi Kesejahteraan Investor (KI), Rasio Kontribusi Kesejahteraan Pemegang Wadiah (KPW), Rasio Kontribusi Pajak untuk Pemerintah (KPP), Kontribusi Peningkatan Kapasitas SDI dan Riset (PKSR), dan Rasio Alokasi untuk Riset dan Pengembangan (R\&D). Penulis tidak mencatumkan dan menghitung komponen DPE karena data yang mendukung penelitian tidak ditemukan, sehingga penulis hanya menggunakan 4 teori yaitu KPE, KKM, KUS, dan PKSR. Dari keterangan tersebut, peneliti mengambil judul "Perbandingan Kinerja Sosial Pda Bank Umum Syariah di Indonesia Periode2013-2016".

\section{LANDASAN TEORI}

Menurut Muhammad (2005:13) Bank Umum Syariah adalah bank yang melakukan kegiatan usaha atau beroperasi berdasarkan prinsip syariah dan tidak mengandalkan pada bunga dalam memberikan pembiayaan dan jasa-jasa lainnya dalam lalu lintas pembayaran. Hal ini termasuk dalam menerapkan prinsip Islam berikut: (1) Menolak adanya bunga (riba), (2) 
Soegiharto, et al/Jurnal Ekonomi Syariah Teori dan Terapan Vol. 6 No. 1 Januari 2019: 42-58; PERBANDINGAN CORPORATE SOCIAL PERFORMANCE PADA BANK UMUM SYARIAH DI INDONESIA PERIODE 2013-2016 (STUDI PADA BSM, BMI, BRIS, BNIS, BMS, BVS, BCAS, BPS, BSB, BJBS, MS, DAN BAS)

Melarang gharar (ketidakpastian, resiko, dan spekulasi) (3), Fokus pada kegiatankegiatan yang halal, (4) Secara umum mencari keadilan, sesuai etika dan tujuan syariah, (5) Pembagian keuntungan dan kerugian antara bank dan konsumen/nasabah.

Bank di Indonesia dibedakan menjadi bank konvensional dan bank syariah. Secara garis besar, tidak ada perbedaan fungsi antara bank syariah dan bank konvensional sebagai Financial Intermediary. Perbedaan pokoknya terletak dalam perlakuan dan jenis keuntungan yang diambil bank. Bank konvensional mengambil keuntungan dari bunga, sedangkan bank syariah mengambil dari imbalan, baik berupa jasa (fee-based income) maupun mark up atau profit margin serta bagi hasil (loss and profit sharing) (Rivai dan Arifin 2010:33).

Fungsi sosial bank syariah tersebut sejalan dengan teori Corporate Social Responsibility (CSR) yang bertujuan agar perusahaan tidak hanya menjalankan kepentingan para pemegang saham (shareholder) saja, tetapi juga memperhatikan kepentingan stakeholder yang terdiri dari para pekerja, komunitas local, pemerintah, LSM, konsumen, dan lingkungan (Susanto, 2009: 109-118). CSR merupakan kepedulian perusahaan yang didasari tiga prisip dasar yang dikenal dengan Triple Bottom Lines (3P), yaitu Profit, People, dan Planet. Dengan prinsip $3 P$ ini, tujuan bisnis tidak lagi hanya persoalan finansial atau laba (profit), tetapi juga harus menyejahterakan orang (people) dan menjamin kelanjutan hidup planet ini (planet) (Alma dan Donni, 2009: 191).

Setiawan (2009) melalui jurnalnya telah mengembangkan sebuah alat yang dinamakan rasio kinerja sosial, yang didalamnya terdiri dari:

1. Rasio MMR digunakan untuk mengukur besarnya fungsi intermediasi bank syariah melalui penyaluran dana dengan akad profit sharing.

MMR $\frac{\text { Mudharabah+Musyarahah }}{\text { Total Pembiayaan }}$

2. Rasio $A R$ digunakan untuk mengukur besarnya fungsi agency bank syariah dalam menghimpun dana investasi masyarakat.

AR $\frac{\text { DHK-NIII }}{\text { Total DPR }}$

. Rasio KPJP digunakan untuk mengukur seberapa besar pembiayaan yang berjangka waktu diatas 5 tahun.

KPJP $=\frac{\text { Pembiayagn diatas 5th }}{\text { Total Aset }}$

4. Rasio PFA digunakan untuk mengukur seberapa besar fungsi agency bank syariah dalam menghimpun dana investasi masyarakat.

PFA $=\frac{\text { Deposito\&obligasi mudharabah }}{\text { Total Kewajiban }}$

5. Rasio QR digunakan untuk mengukur besarnya kontribusi pembiayaan qardh bank syariah tersebut.

$\mathrm{QR}=\frac{\text { Pembiayasn Qard }}{\text { Total Pembiaysan }}$....

6. Rasio ZR digunakan untuk mengukur besarnya kontribusi zakat perusahaan yang dikeluarkan oleh bank syariah.

$\mathrm{ZR}=\frac{\text { Penyaluran Zakat Perusahasn }}{\text { Laba Sebelum Pajak }}$ 
Soegiharto, et al/Jurnal Ekonomi Syariah Teori dan Terapan Vol. 6 No. 1 Januari 2019: 42-58; PERBANDINGAN CORPORATE SOCIAL PERFORMANCE PADA BANK UMUM SYARIAH DI INDONESIA PERIODE 2013-2016 (STUDI PADA BSM, BMI, BRIS, BNIS, BMS, BVS, BCAS, BPS, BSB, BJBS, MS, DAN BAS)

7. Rasio RFS digunakan untuk mengukur besarnya pelaksanaan fungsi sosial bank syariah.

RFS $=\frac{\text { Dana Zakat dan Kebajikan }}{\text { Modal Inti }}$

8. Rasio CSR digunakan untuk mengukur besar fungsi corporate social responsibility terhadap proses pembelajaran masyarakat.

$\mathrm{CSR}=\frac{\text { Biaya Promosi }}{\text { Biaya Operasional }}$

9. Rasio KSM digunakan untuk mengukur besarnya keuntungan bank syariah yang dinikmati oleh pemegang saham yang akan ditandai dengan meningkatnya laba yang ditahan oleh perusahaan.

KSM $=\frac{\text { Laba Setelah Pajak }}{\text { Modal Inti (Total Ekuitas) }}$.

10. Rasio KM digunakan untuk mengukur besarnya proporsi alokasi pendapatan operasional bank syariah yang dinikmati oleh manajemen dan pegawai dalam bentuk gaji dan tunjangan.

$\mathrm{KM}=\frac{\text { Biaya Gaji dan Kesejahteraan }}{\text { Pendapatan Operasional }}$

11. Rasio KI digunakan untuk mengukur besarnya keuntungan bank syariah yang dinikmati oleh pemilik rekening tabungan dan deposito mudharabah.

$\mathrm{KI}=\frac{\text { Distribusi Bagi HasiI }}{\text { Total DPK }- \text { ITT }}$

12. Rasio digunakan untuk mengukur besarnya keuntungan bank syariah yang dinikmati oleh pemilik rekening gito dan tabungan wadiah.

$\mathrm{KPW}=\frac{\text { Bonus Rekening Wadiah }}{\text { Total DPKWadiah }}$

13. Rasio KPP digunakan untuk mengukur besarnya kontribusi pembayaran pajak bank syariah yang diterima oleh pemerintah.
$\mathrm{KPP}=\frac{\text { Beban Pajak Penghasilan Bersih }}{\text { Pendapatan Operasional }}$

14. Rasio PKSR digunakan untuk mengukur besarnya alokasi dana untuk program pendidikan dan pelatihan pegawai.

PKSR $=\frac{\text { Biaya Pendidikan dan Pelatihan }}{\text {. }}$

15. Rasio R\&D digunakan untuk mengukur besarnya alokasi dana untuk program riset dan pengembangan institusinya.

$\mathrm{R} \& D=\frac{\text { Biaya Riset dan Development }}{\text { Laba Setelah Pajak }}$.

\section{METODE PENELITIAN}

\section{Pendekatan Penelitian}

Pendekatan yang dipergunakan dalam penelitian ini adalah pendekatan kuantitatif. Menurut Sugiyono (2013:13) metode penelitian kuantitatif adalah metode penelitian yang berlandaskan filsafat, positivism, digunakan untuk meneliti pada populasi atau sampel tertentu, pengumpulan data menggunakan instrumen penelitian, analisis data bersifat kuantitatif/statistik dengan tujuan untuk menguji hipotesis yang telah ditetapkan.

Teknik analisis yang digunakan adalah statistik deskriptif, yaitu teknik statistik yang dipergunakan untuk menganalisis data dengan mendeskripsikan data yang telah terkumpul sebelumnya.

\section{Identifikasi Variabel}

Variabel penelitian merupakan segala sesuatu yang dibentuk apa saja yang ditetapkan peneliti untuk dipelajari, sehingga diperoleh informasi tentang hal tersebut yang kemudian dibuat kesimpulannya (Anshori dan Iswati, 
Soegiharto, et al/Jurnal Ekonomi Syariah Teori dan Terapan Vol. 6 No. 1 Januari 2019: 42-58; PERBANDINGAN CORPORATE SOCIAL PERFORMANCE PADA BANK UMUM SYARIAH DI INDONESIA PERIODE 2013-2016 (STUDI PADA BSM, BMI, BRIS, BNIS, BMS, BVS, BCAS, BPS, BSB, BJBS, MS, DAN BAS)

2009:57). Berdasarkan rumusan masalah, maka variabel dalam penelitian ini adalah MMR, AR, KPJP, PFA QR, ZR, RFS, CSR, KSM, $K M, K I, K P W, K P P, P K S R, R \& D$.

\section{Jenis dan Sumber Data}

Jenis data yang digunakan dalam penelitian ini adalah data sekunder. Data sekunder pada umumnya berupa bukti, catatan, atau laporan historis yang telah tersusun dalam arsip yang dipublikasikan dan yang tidak dipublikasikan (Indriantoro dkk, 2002:147). Data sekunder dalam penelitian ini berupa laporan keuangan tahunan Bank Umum Syariah yang terdapat di situs website resmi laporan publikasi bank tersebut yang dimulai tahun 2013-2016. Sumber-sumber lain juga digunakan dalam penelitian ini seperti buku, literatur, penelitian terdahulu, dan artikel dari internet.

\section{Sampel}

Teknik purposive sampling adalah teknik penentuan sampel dengan pertimbangan tertentu (Ansori dan Iswati, 2009:105). Adapun pemilihan sampel berdasarkan pertimbangan sebagai berikut:

1. Merupakan Bank Umum Syariah di Indonesia

2. Bank Syariah yang mempublikasikan laporan keuangan tahunan periode 2013-2016

3. Memiliki data rasio kinerja sosial

\section{Prosedur Pengumpulan Data}

Prosedur pengumpulan data yang dilakukan peneliti adalah sebagai berikut:

1. Metode pengumpulan data tidak langsung
Dilakukan dengan mengumpulkan data penelitian yang bersumber dari data sekunder, yaitu laporan keuangan tahunan 31 Desember 2013 hingga 31 Desember 2016 yang terdapat pada website masing-masing bank yang dijadikan sampel penelitian.

2. Studi Kepustakaan

Dilakukan dengan mengumpulkan dan mempelajari berbagai jurnal, buku, artikel, peneltian terdahulu dan bahan-bahan lain yang digunakan untuk memahami permasalahan dan mendapatkan alternatif pemecahan masalah tersebut.

\section{Teknik Analisis}

Teknik analisis data dalam penelitian kuantitatif menggunakan analisis statistik. Analisis data dalam penelitian ini menggunakan dua tahap, yaitu satistik deskriptif dan statistik inferensial.

Statistik deskriptif adalah metode mengatur, merangkum, dan mempresentasikan data dengan cara informatif (Lind, 2013:6). Statistik deskriptif menyajikan nilai rata-rata (mean), niali terendah (minimum) dan nilai tertinggi (maximum) dari rasio-rasio yang diujikan yaitu rasio $M M R, A R, K P J P, P F A Q R, Z R, R F S$, CSR, KSM, KM, KI, KPW, KPP, PKSR, R\&D yang dimiliki bank yang menjadi sampel selama periode 2013 hingga 2016. Statistik deskriptif pada penelitian ini menggunakan program Ms.Excel 2016.

Teknik statistik inferensial digunakan untuk menganalisis data sampel dan 
Soegiharto, et al/Jurnal Ekonomi Syariah Teori dan Terapan Vol. 6 No. 1 Januari 2019: 42-58; PERBANDINGAN CORPORATE SOCIAL PERFORMANCE PADA BANK UMUM SYARIAH DI INDONESIA PERIODE 2013-2016 (STUDI PADA BSM, BMI, BRIS, BNIS, BMS, BVS, BCAS, BPS, BSB, BJBS, MS, DAN BAS)

hasilnya diberlakukan untuk populasinya (Anshori dan Iswati, 2009:123). Statistik inferensial dalam penelitian ini menggunakan analisis parametrik dengan Uji Anova dan juga analisis non parametrik dengan Uji kruskal wallis dengan menggunakan aplikasi SPSS 20.

\section{HASIL DAN PEMBAHASAN}

Setelah dilakukan analisis deskriptif dilanjutkan dengan melakukan analisisindicator untuk mengukur bisnis model serta stabilitas pada bank umum syariah dan bank umum konvensional, dilanjutkan dengan uji normalitas yang menjadi persyaratan sebelum melakukan uji beda.

Data uji normalitas adalah rasio MMR, $A R, K P J P, P F A Q R, Z R, R F S, C S R, K S M, K M$, KI, KPW, KPP, PKSR, R\&D pada bank umum syariah dan bank umum konvensional selama periode 31 Desember 2013- 31 Desember 2016 dapat dilihat pada Tabel dibawah ini:

Tabel 1. Uji Normalitas

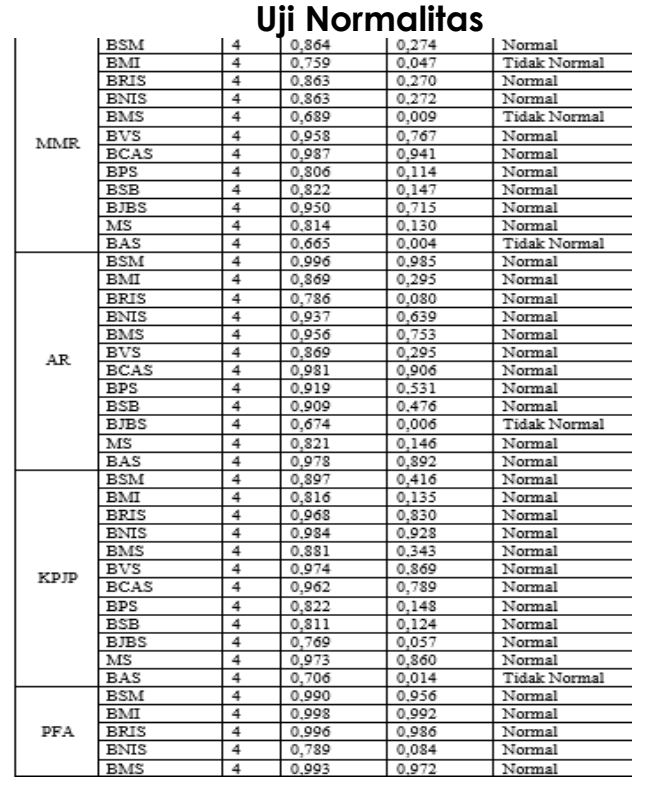

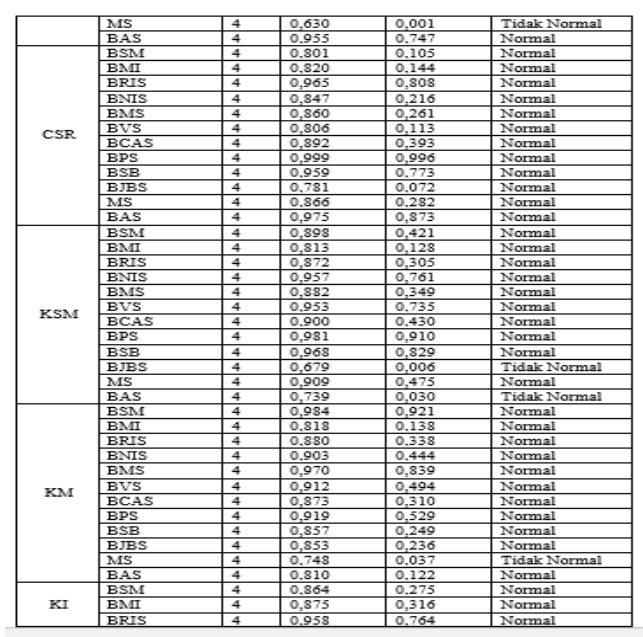
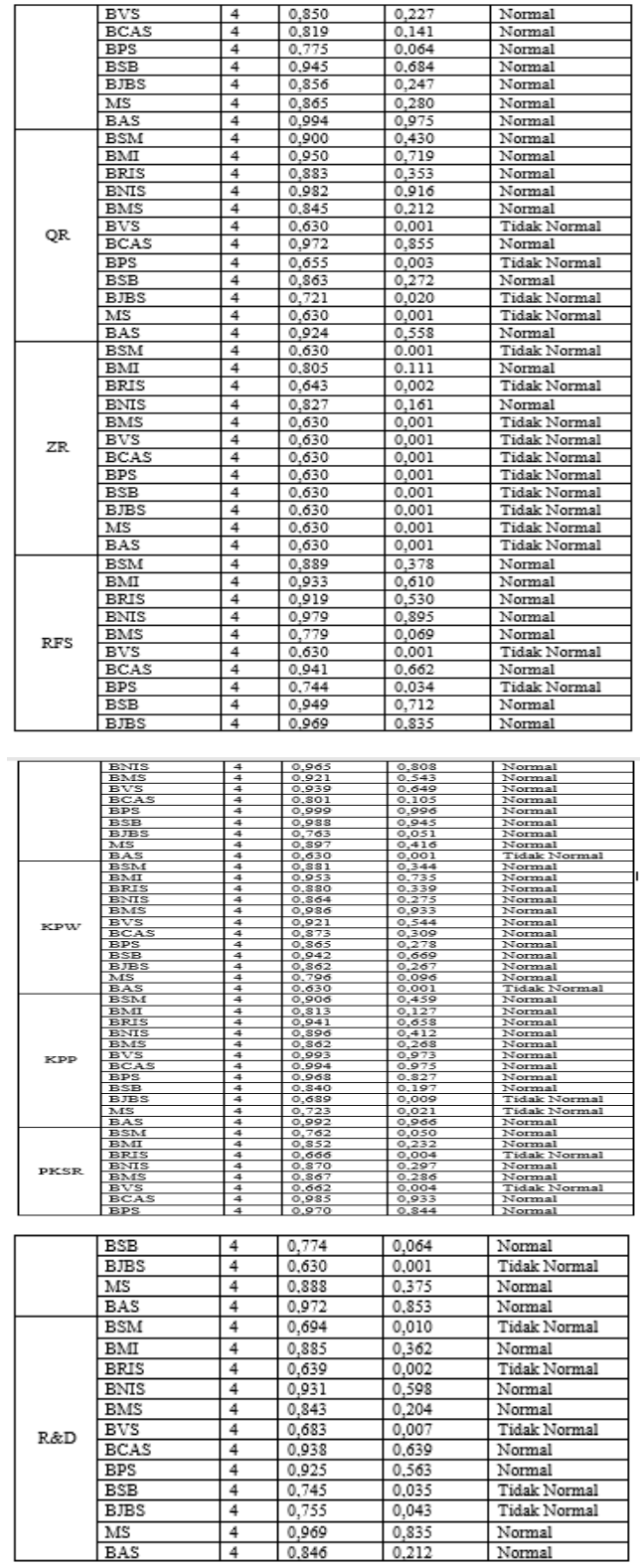

Sumber: hasil uji SPSS (data telah diolah) 
Soegiharto, et al/Jurnal Ekonomi Syariah Teori dan Terapan Vol. 6 No. 1 Januari 2019: 42-58; PERBANDINGAN CORPORATE SOCIAL PERFORMANCE PADA BANK UMUM SYARIAH DI INDONESIA PERIODE 2013-2016 (STUDI PADA BSM, BMI, BRIS, BNIS, BMS, BVS, BCAS, BPS, BSB, BJBS, MS, DAN BAS)

Dari hasil uji normalitas menjelaskanbahwa untuk variabel CSR dan PFA pada Bank Umum Syariah di Indonesia dinyatakan berdistribusi normal karena seluruh data memiliki nilai signifikansi diatas 0,05 . Sedangkan untuk variabel MMR, AR, KPJP, QR, ZR, RFS, KSM, $K M, K I, K P W, K P P, \quad P K S R, \quad R \& D p a d a$ beberapa bank syariah di Indonesia memiliki signifikansi kurang dari 0,05 sehingga dapat dinyatakan data tidak terdistribusi normal.

Dari hasil uji normalitas tersebut, maka dapat disimpulkan bahwa untuk variabel CSR dan PFA dapat dilakukan uji beda menggunakan Anova dikarenakan variabel tersebut telah memiliki nilai signifikansi diatas 0,05, sedangkan untuk variabel MMR, AR, KPJP, QR, ZR, RFS, KSM, KM, KI, KPW, KPP, PKSR, R\&D dapat dilakukan uji beda dengan menggunakan uji Kruskal Wallisdikarenakan data variabel tersebut tidak berdistribusi normal.

\section{Uji Beda}

Uji Beda MMR

Tabel 2.

Kruskal-Wallis Test

\begin{tabular}{|c|c|c|c|c|c|c|c|c|c|c|c|c|c|c|}
\hline \multicolumn{7}{|c|}{ Kruskal-Waillis lest } & \multirow{2}{*}{\multicolumn{8}{|c|}{$\begin{array}{l}\text { signifikansi dari variabel ini adalah } 0,001 \\
\text { atau lebih kecil dari } 0,05 \text { sehingga dapat }\end{array}$}} \\
\hline $\begin{array}{c}\text { Variab } \\
\text { el }\end{array}$ & $\begin{array}{c}\text { Negar } \\
\text { a }\end{array}$ & $\begin{array}{l}\text { Mean } \\
\text { Rank }\end{array}$ & Df & $\begin{array}{c}\text { Chi } \\
\text { Square }\end{array}$ & Sig & Ket. & & & & & & & & \\
\hline \multirow{12}{*}{ MMR } & BSM & 21,50 & \multirow{12}{*}{11} & \multirow{12}{*}{38,959} & \multirow{12}{*}{0,000} & \multirow{12}{*}{$\begin{array}{c}\mathrm{H}_{0} \\
\text { ditolak } \\
\text { (terda } \\
\text { pat } \\
\text { perbe } \\
\text { daan) }\end{array}$} & \multirow{8}{*}{\multicolumn{8}{|c|}{$\begin{array}{l}\text { dinyatakan bahwa terdapat perbedaan } \\
\text { signifikan variabel AR pada Bank Umum } \\
\text { Syariah di Indonesia periode 2013-2016. } \\
\text { Uji Beda KPJP } \\
\text { Tabel 4. } \\
\text { Kruskal-Wallis Test }\end{array}$}} \\
\hline & BMI & 38,50 & & & & & & & & & & & & \\
\hline & BRIS & 27,00 & & & & & & & & & & & & \\
\hline & BNIS & 16,00 & & & & & & & & & & & & \\
\hline & BMS & 5,25 & & & & & & & & & & & & \\
\hline & BVS & 40,50 & & & & & & & & & & & & \\
\hline & BCAS & 37,75 & & & & & & & & & & & & \\
\hline & BPS & 42,00 & & & & & & & & & & & & \\
\hline & BSB & 26,13 & & & & & \multirow[t]{2}{*}{ Variabel } & & Negara & Mean & Df & Chi & Sig & Keterangan \\
\hline & BJBS & 22,25 & & & & & & & & & & \multirow{4}{*}{35,691} & & \\
\hline & MS & 9,38 & & & & & \multirow{3}{*}{ KPJP } & & BSM & 24,75 & \multirow{3}{*}{11} & & \multirow{3}{*}{0,000} & \multirow{3}{*}{$\begin{array}{c}\mathrm{H}_{0} \text { ditolak } \\
\text { (terdapat } \\
\text { perbedaan) }\end{array}$} \\
\hline & BAS & 7,75 & & & & & & & BMI & 30,00 & & & & \\
\hline & & & $\begin{array}{l}\text { BRIS } \\
\text { BNIS }\end{array}$ & $\begin{array}{l}17,25 \\
40,50\end{array}$ & & & & \\
\hline
\end{tabular}

Tabel 3.

Kruskal-Wallis Test

\begin{tabular}{|c|c|c|c|c|c|c|}
\hline $\begin{array}{c}\text { Varia } \\
\text { bel }\end{array}$ & Negara & $\begin{array}{l}\text { Mean } \\
\text { Rank }\end{array}$ & Df & $\begin{array}{c}\text { Chi } \\
\text { Square }\end{array}$ & Sig & Ket. \\
\hline \multirow{12}{*}{ AR } & BSM & 17,25 & \multirow{12}{*}{11} & \multirow{12}{*}{32,979} & \multirow{12}{*}{0,001} & \multirow{12}{*}{$\begin{array}{c}\mathrm{H} 0 \\
\text { ditolak } \\
\text { (terda } \\
\text { pat } \\
\text { perbe } \\
\text { daan) }\end{array}$} \\
\hline & BMI & 33,13 & & & & \\
\hline & BRIS & 6,75 & & & & \\
\hline & BNIS & 17,00 & & & & \\
\hline & BMS & 18,00 & & & & \\
\hline & BVS & 44,75 & & & & \\
\hline & BCAS & 23,75 & & & & \\
\hline & BPS & 29,50 & & & & \\
\hline & BSB & 32,75 & & & & \\
\hline & BJBS & 32,50 & & & & \\
\hline & MS & 34,38 & & & & \\
\hline & BAS & 4,25 & & & & \\
\hline
\end{tabular}

Sumber: hasil uji SPSS (data telah diolah).

Berdasarkan tabel 3 hasil uji beda

Kruskal Wallisdiketahui bahwa nilai signifikansi dari variabel ini adalah 0,001 .

(n)


Soegiharto, et al/Jurnal Ekonomi Syariah Teori dan Terapan Vol. 6 No. 1 Januari 2019: 42-58; PERBANDINGAN CORPORATE SOCIAL PERFORMANCE PADA BANK UMUM SYARIAH DI INDONESIA PERIODE 2013-2016 (STUDI PADA BSM, BMI, BRIS, BNIS, BMS, BVS, BCAS, BPS, BSB, BJBS, MS, DAN BAS)

\begin{tabular}{|l|c|}
\hline BMS & 3,50 \\
\hline BVS & 26,25 \\
\hline BCAS & 8,00 \\
\hline BPS & 27,25 \\
\hline BSB & 26,25 \\
\hline BJBS & 31,50 \\
\hline MS & 12,25 \\
\hline BAS & 46,50 \\
\hline
\end{tabular}

Sumber: hasil uji SPSS (data telah dioalah)

Berdasarkan tabel 4 hasil uji beda kruskal wallis dilakukan pada variabel KPJP untuk Bank Umum Syariah di Indonesia, diketahui bahwa nilai signifikansi dari variabel ini adalah 0,000 atau lebih kecil dari 0,05 sehingga dapat dinyatakan bahwa terdapat perbedaan signifikan variabel KPJP pada Bank Umum Syariah di Indonesia periode 2013-2016.

Uji PFA

Tabel 5.

Uji ANOVA

\begin{tabular}{|c|c|c|c|c|c|}
\hline $\begin{array}{c}\text { Variabe } \\
\text { I }\end{array}$ & $\begin{array}{c}\text { Negar } \\
a\end{array}$ & Df & $F$ & Sig. & $\begin{array}{c}\text { Keteranga } \\
n\end{array}$ \\
\hline \multirow{13}{*}{ PFA } & BSM & \multirow{13}{*}{4} & \multirow{13}{*}{$\begin{array}{c}6,49 \\
4\end{array}$} & \multirow{13}{*}{$\begin{array}{c}0,00 \\
0\end{array}$} & \multirow{13}{*}{$\begin{array}{l}\text { Ho ditolak } \\
\text { (terdapat } \\
\text { Perbedaan }\end{array}$} \\
\hline & BMI & & & & \\
\hline & BRIS & & & & \\
\hline & & & & & \\
\hline & BNIS & & & & \\
\hline & BMS & & & & \\
\hline & BVS & & & & \\
\hline & BCAS & & & & \\
\hline & BPS & & & & \\
\hline & BSB & & & & \\
\hline & BJBS & & & & \\
\hline & MS & & & & \\
\hline & BAS & & & & \\
\hline
\end{tabular}

Sumber: hasil uji SPSS (data telah diolah).

Berdasarkan Tabel 6hasil uji beda Anova yang dilakukan pada variabel PFA pada Bank Umum Syariah di Indonesia, diketahui bahwa derajat kebebasan adalah 47 dan nilai signifikansi dari variabel ini adalah 0,000 atau lebih kecil dari 0,05 sehingga dinyatakan terdapat perbedaan signifikan variabel PFA pada Bank Umum Syariah di Indonesia periode 2013-2016.

\section{Uji Beda $Q R$}

Tabel 6.

Kruskal-Wallis Test

\begin{tabular}{|c|c|c|c|c|c|c|}
\hline Variabel & Negara & $\begin{array}{c}\text { Mean } \\
\text { Rank }\end{array}$ & Df & $\begin{array}{c}\text { Chi } \\
\text { Square }\end{array}$ & Sig & Ket. \\
\hline \multirow{12}{*}{ QR } & BSM & 38,75 & \multirow{12}{*}{11} & \multirow{12}{*}{39,979} & \multirow{12}{*}{0,000} & \multirow{12}{*}{$\begin{array}{c}\mathrm{H}_{0} \\
\text { ditolak } \\
\text { (terdap } \\
\text { at } \\
\text { perbed } \\
\text { aan) }\end{array}$} \\
\hline & $\mathrm{BMI}$ & 23,50 & & & & \\
\hline & BRIS & 31,25 & & & & \\
\hline & BNIS & 38,75 & & & & \\
\hline & BMS & 43,25 & & & & \\
\hline & BVS & 7,13 & & & & \\
\hline & BCAS & 14,75 & & & & \\
\hline & BPS & 11,00 & & & & \\
\hline & BSB & 16,38 & & & & \\
\hline & BJBS & 23,88 & & & & \\
\hline & MS & 7,13 & & & & \\
\hline & BAS & 38,25 & & & & \\
\hline
\end{tabular}

Sumber: hasil uji SPSS(data telah diolah)

Berdasarkan tabel 6hasil uji beda Anova dilakukan pada variabel $Q R$ untuk Bank Umum Syariah di Indonesia, diketahui bahwa nilai signifikansi dari variabel ini adalah 0,000 atau lebih kecil dari 0,05 sehingga dapat dinyatakan bahwa terdapat perbedaan signifikan variabel QR pada Bank Umum Syariah di Indonesia periode 2013-2016.

Uji ZR

Tabel 7.

Kruskal -Wallis Test

\begin{tabular}{|c|c|c|c|c|c|c|}
\hline $\begin{array}{c}\text { Varia } \\
\text { bel }\end{array}$ & $\begin{array}{c}\text { Negar } \\
\text { a }\end{array}$ & $\begin{array}{l}\text { Mean } \\
\text { Rank }\end{array}$ & Df & $\begin{array}{c}\text { Chi } \\
\text { Square }\end{array}$ & Sig & Ket. \\
\hline \multirow{7}{*}{ ZR } & BSM & 38,38 & \multirow{7}{*}{11} & \multirow{7}{*}{39,123} & \multirow{7}{*}{$\begin{array}{c}0,00 \\
0\end{array}$} & \multirow{7}{*}{$\begin{array}{l}\text { } \mathrm{H}_{0} \\
\text { ditolak } \\
\text { terdap } \\
\text { at } \\
\text { Perbed } \\
\text { aan }\end{array}$} \\
\hline & BMI & 36,50 & & & & \\
\hline & BRIS & 41,25 & & & & \\
\hline & BNIS & 30,50 & & & & \\
\hline & BMS & 38,38 & & & & \\
\hline & BVS & 12,50 & & & & \\
\hline & BCAS & 12,50 & & & & \\
\hline
\end{tabular}


Soegiharto, et al/Jurnal Ekonomi Syariah Teori dan Terapan Vol. 6 No. 1 Januari 2019: 42-58; PERBANDINGAN CORPORATE SOCIAL PERFORMANCE PADA BANK UMUM SYARIAH DI INDONESIA PERIODE 2013-2016 (STUDI PADA BSM, BMI, BRIS, BNIS, BMS, BVS, BCAS, BPS, BSB, BJBS, MS, DAN BAS)

\begin{tabular}{|l|l|}
\hline BPS & 34,00 \\
\hline BSB & 12,50 \\
\hline BJBS & 12,50 \\
\hline MS & 12,50 \\
\hline BAS & 12,50 \\
\hline
\end{tabular}

Sumber: hasil uji SPSS(data telah diolah)

Hasil uji beda Anova dilakukan pada variabel Kinerja Zakat (ZR) untuk Bank Umum Syariah di Indonesia, diketahui bahwa nilai signifikansi dari variabel ini adalah 0,000 atau lebih kecil dari 0,05 sehingga dapat dinyatakan bahwa terdapat perbedaan signifikan variabel ZR pada Bank Umum Syariah di Indonesia periode 2013-2016.

Uji RFS

Tabel 8.

Kruskal-Wallis Test Variabel Pelaksanaan Fungsi Sosial (RFS)

\begin{tabular}{|c|c|c|c|c|c|c|}
\hline $\begin{array}{l}\text { Vari } \\
\text { abel }\end{array}$ & $\begin{array}{c}\text { Nega } \\
\text { ra }\end{array}$ & $\begin{array}{l}\text { Mean } \\
\text { Rank }\end{array}$ & Df & $\begin{array}{c}\text { Chi } \\
\text { Square }\end{array}$ & Sig & Ket. \\
\hline \multirow{12}{*}{ RFS } & BSM & 44,00 & \multirow{12}{*}{11} & \multirow{12}{*}{40,040} & \multirow{12}{*}{0,000} & \multirow{12}{*}{$\begin{array}{c}\mathrm{H}_{0} \\
\text { ditolak } \\
\text { (terdap } \\
\text { at } \\
\text { Perbed } \\
\text { aan) }\end{array}$} \\
\hline & BMI & 31,50 & & & & \\
\hline & BRIS & 39,25 & & & & \\
\hline & BNIS & 41,75 & & & & \\
\hline & BMS & 32,25 & & & & \\
\hline & BVS & 5,75 & & & & \\
\hline & BCAS & 12,63 & & & & \\
\hline & BPS & 18,63 & & & & \\
\hline & BSB & 17,75 & & & & \\
\hline & BJBS & 25,13 & & & & \\
\hline & MS & 5,75 & & & & \\
\hline & BAS & 19,63 & & & & \\
\hline
\end{tabular}

Sumber: hasil uji SPSS(data telah diolah)

hasil uji beda Anova dilakukan pada variabel RFS untuk Bank Umum Syariah di Indonesia, diketahui bahwa nilai signifikansi dari variabel ini adalah 0,000 atau lebih kecil dari 0,05 sehingga dapat dinyatakan bahwa terdapat perbedaan signifikan variabel RFS pada Bank Umum Syariah di Indonesia periode 2013-2016.

Uji CSR

Tabel 9.

Uji ANOVA

Variabel Pelaksanaan Fungsi Edukasi (CSR)

\begin{tabular}{|c|c|c|c|c|c|}
\hline Variabel & Negara & Df & $\mathrm{F}$ & Sig. & Ket. \\
\hline \multirow{12}{*}{ CSR } & BSM & \multirow{12}{*}{47} & \multirow{12}{*}{1,832} & \multirow{12}{*}{0,084} & \multirow{12}{*}{$\begin{array}{l}\text { HO diterima } \\
\text { (tdk } \\
\text { terdapat } \\
\text { Perbedaan } \\
\text { Signifikan) }\end{array}$} \\
\hline & BMI & & & & \\
\hline & BRIS & & & & \\
\hline & BNIS & & & & \\
\hline & BMS & & & & \\
\hline & BVS & & & & \\
\hline & BCAS & & & & \\
\hline & BPS & & & & \\
\hline & BSB & & & & \\
\hline & BJBS & & & & \\
\hline & $M S$ & & & & \\
\hline & BAS & & & & \\
\hline
\end{tabular}

Sumber: hasil uji SPSS(data telah diolah)

hasil uji beda Anova yang dilakukan pada variabel CSR pada Bank Umum Syariah di Indonesia, diketahui bahwa derajat kebebasan adalah 47 dan nilai signifikansi dari variabel ini adalah 0,084 atau lebih besar dari 0,05 sehingga dinyatakan tidak terdapat perbedaan signifikan variabel CSR pada Bank Umum Syariah di Indonesia periode 2013-2016.

Uji KSM

Tabel 10.

Kruskal-Wallis Test

Variabel Kontribusi

KesejahteraanShahibul Maal (KSM)

\begin{tabular}{|c|c|c|c|c|c|c|}
\hline Variabel & Negara & $\begin{array}{l}\text { Mean } \\
\text { Rank }\end{array}$ & Df & $\begin{array}{c}\text { Chi } \\
\text { Square }\end{array}$ & Sig & Ket. \\
\hline \multirow{7}{*}{ KSM } & BSM & 23,00 & \multirow{7}{*}{11} & \multirow{7}{*}{20,536} & \multirow{7}{*}{0,039} & \multirow{7}{*}{$\begin{array}{c}\mathrm{H}_{0} \\
\text { ditolak } \\
\text { (terda } \\
\text { pat } \\
\text { Perbed } \\
\text { aan) }\end{array}$} \\
\hline & BMI & 12,25 & & & & \\
\hline & BRIS & 22,00 & & & & \\
\hline & BNIS & 34,50 & & & & \\
\hline & BMS & 23,00 & & & & \\
\hline & BVS & 31,25 & & & & \\
\hline & BCAS & 13,25 & & & & \\
\hline
\end{tabular}


Soegiharto, et al/Jurnal Ekonomi Syariah Teori dan Terapan Vol. 6 No. 1 Januari 2019: 42-58; PERBANDINGAN CORPORATE SOCIAL PERFORMANCE PADA BANK UMUM SYARIAH DI INDONESIA PERIODE 2013-2016 (STUDI PADA BSM, BMI, BRIS, BNIS, BMS, BVS, BCAS, BPS, BSB, BJBS, MS, DAN BAS)

\begin{tabular}{|l|l|l|l|}
\hline BPS & 18,50 & & \\
\hline BSB & 19,00 \\
\hline BJBS & 20,00 \\
\hline MS & 32,00 \\
\hline BAS & 45,25 \\
\hline
\end{tabular}

Sumber: hasil uji SPSS(data telah diolah)

hasil uji beda Anova dilakukan pada variabel Kontribusi Kesejahteraan Shahibul Maal (KSM) untuk Bank Umum Syariah di Indonesia, diketahui bahwa nilai signifikansi dari variabel ini adalah 0,039 atau lebih kecil dari 0,05 sehingga dapat dinyatakan bahwa terdapat perbedaan signifikan variabel KSM pada Bank Umum Syariah di Indonesia periode 2013-2016.

Uji KM

Tabel 11.

Kruskal-Wallis Test

Variabel Alokasi Kesejahteraan Mudharib (KM)

\begin{tabular}{|c|c|c|c|c|c|c|}
\hline Variabel & Negara & $\begin{array}{l}\text { Mean } \\
\text { Rank }\end{array}$ & Df & $\begin{array}{c}\text { Chi } \\
\text { Square }\end{array}$ & Sig & Keterangan \\
\hline \multirow{12}{*}{ KM } & BSM & 27,63 & \multirow{12}{*}{11} & \multirow{12}{*}{31,871} & \multirow{12}{*}{0,001} & \multirow{12}{*}{$\begin{array}{l}\text { HO ditolak } \\
\text { (terdapat } \\
\text { Perbedaa }\end{array}$} \\
\hline & BMI & 15,63 & & & & \\
\hline & BRIS & 28,00 & & & & \\
\hline & BNIS & 43,50 & & & & \\
\hline & BMS & 43,75 & & & & \\
\hline & BVS & 21,50 & & & & \\
\hline & BCAS & 23,75 & & & & \\
\hline & BPS & 2,50 & & & & \\
\hline & BSB & 11,25 & & & & \\
\hline & BJBS & 29,75 & & & & \\
\hline & $M S$ & 27,25 & & & & \\
\hline & BAS & 19,50 & & & & \\
\hline
\end{tabular}

Sumber: hasil uji SPSS (data telah diolah hasil uji beda Anova dilakukan pada variabel Alokasi Kesejahteraan Mudharib (KM) untuk Bank Umum Syariah di Indonesia, diketahui bahwa nilai signifikansi dari variabel ini adalah 0,001 sehingga dapat dinyatakan bahwa terdapat perbedaan signifikan variabel
KM pada Bank Umum Syariah di Indonesia periode 2013-2016.

UJi KI

Tabel 12.

Kruskal-Wallis Test Variabel Kontribusi Kesejahteraan Investor (KI)

\begin{tabular}{|c|c|c|c|c|c|c|}
\hline $\begin{array}{c}\text { Varia } \\
\text { bel }\end{array}$ & Negara & $\begin{array}{l}\text { Mean } \\
\text { Rank }\end{array}$ & Df & $\begin{array}{l}\text { Chi } \\
\text { Square }\end{array}$ & Sig & Ket. \\
\hline \multirow{12}{*}{ KI } & BSM & 10,75 & \multirow{12}{*}{11} & \multirow{12}{*}{27,376} & \multirow{12}{*}{0,004} & \multirow{12}{*}{$\begin{array}{c}\mathrm{H} 0 \\
\text { ditolak } \\
\text { (terdapa } \\
\dagger \\
\text { Perbeda } \\
\text { an) }\end{array}$} \\
\hline & BMI & 29,50 & & & & \\
\hline & BRIS & 30,25 & & & & \\
\hline & BNIS & 12,75 & & & & \\
\hline & BMS & 29,00 & & & & \\
\hline & BVS & 36,75 & & & & \\
\hline & BCAS & 24,00 & & & & \\
\hline & BPS & 28,00 & & & & \\
\hline & BSB & 40,25 & & & & \\
\hline & BJBS & 30,63 & & & & \\
\hline & MS & 19,00 & & & & \\
\hline & BAS & 3,13 & & & & \\
\hline
\end{tabular}

Sumber: hasil uji SPSS (data telah diolah

hasil uji beda Anova dilakukan pada variabel Alokasi Kesejahteraan Investor (KI) untuk Bank Umum Syariah di Indonesia, diketahui bahwa nilai signifikansi dari variabel ini adalah 0,004 atau lebih kecil dari 0,05 sehingga dapat dinyatakan bahwa terdapat perbedaan signifikan variabel $\mathrm{KI}$ pada Bank Umum Syariah di Indonesia periode 2013-2016.

\section{Uji KPW}

Tabel 13.

Kruskal-Wallis Test Variabel Kontribusi Kesejahteraan Pemegang Wadiah(KPW)

\begin{tabular}{|c|c|c|c|c|c|c|}
\hline Variabel & Negara & $\begin{array}{l}\text { Mean } \\
\text { Rank }\end{array}$ & Df & $\begin{array}{c}\text { Chi } \\
\text { Square }\end{array}$ & Sig & Ket. \\
\hline \multirow{6}{*}{ KPW } & BSM & 16,38 & \multirow{6}{*}{11} & \multirow{6}{*}{40,179} & \multirow{6}{*}{0,000} & \multirow{6}{*}{$\begin{array}{c}\text { Ho ditolak } \\
\text { (terdapa } \\
\dagger \\
\text { Perbeda } \\
\text { an) }\end{array}$} \\
\hline & $\mathrm{BMI}$ & 10,75 & & & & \\
\hline & BRIS & 17,13 & & & & \\
\hline & BNIS & 11,38 & & & & \\
\hline & BMS & 46,50 & & & & \\
\hline & BVS & 38,50 & & & & \\
\hline
\end{tabular}


Soegiharto, et al/Jurnal Ekonomi Syariah Teori dan Terapan Vol. 6 No. 1 Januari 2019: 42-58; PERBANDINGAN CORPORATE SOCIAL PERFORMANCE PADA BANK UMUM SYARIAH DI INDONESIA PERIODE 2013-2016 (STUDI PADA BSM, BMI, BRIS, BNIS, BMS, BVS, BCAS, BPS, BSB, BJBS, MS, DAN BAS)

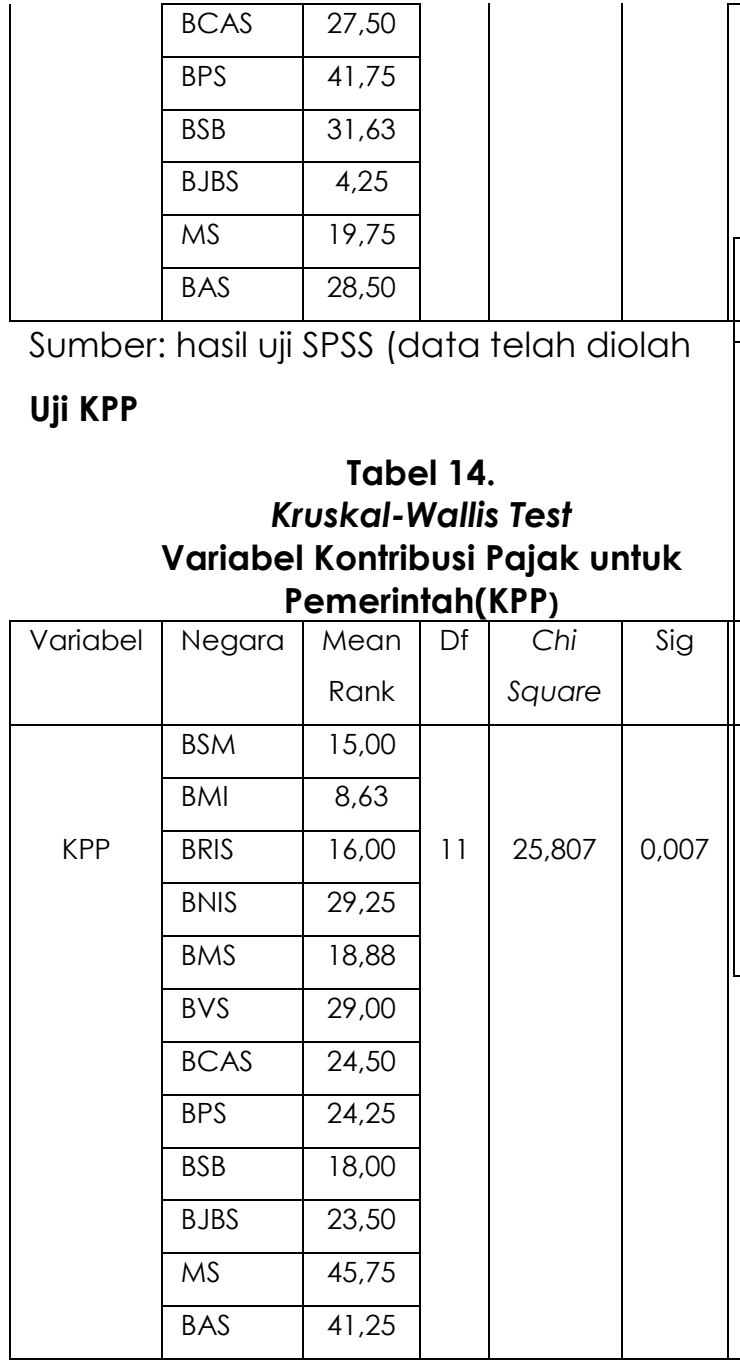

Sumber: hasil uji SPSS (data telah diolah

Uji PKSR

Tabel 15.

Kruskal-Wallis Test

Variabel Kontribusi Peningkatan Kapasitas SDI\&Riset(PKSR)

\begin{tabular}{|c|c|c|c|c|c|c|}
\hline Variabel & Negara & $\begin{array}{l}\text { Mean } \\
\text { Rank }\end{array}$ & Df & $\begin{array}{c}\text { Chi } \\
\text { Square }\end{array}$ & Sig & Keterangan \\
\hline \multirow{12}{*}{ PKSR } & BSM & 34,25 & \multirow{12}{*}{11} & \multirow{12}{*}{32,270} & \multirow{12}{*}{0,001} & \multirow{12}{*}{$\begin{array}{l}\text { Ho ditolak } \\
\text { (terdapat } \\
\text { Perbedaa }\end{array}$} \\
\hline & BMI & 42,50 & & & & \\
\hline & BRIS & 30,00 & & & & \\
\hline & BNIS & 36,00 & & & & \\
\hline & BMS & 26,50 & & & & \\
\hline & BVS & 16,13 & & & & \\
\hline & BCAS & 26,50 & & & & \\
\hline & BPS & 17,88 & & & & \\
\hline & BSB & 35,25 & & & & \\
\hline & BJBS & 2,50 & & & & \\
\hline & MS & 9,75 & & & & \\
\hline & BAS & 16,75 & & & & \\
\hline
\end{tabular}

Sumber: hasil uji SPSS (data telah diolah

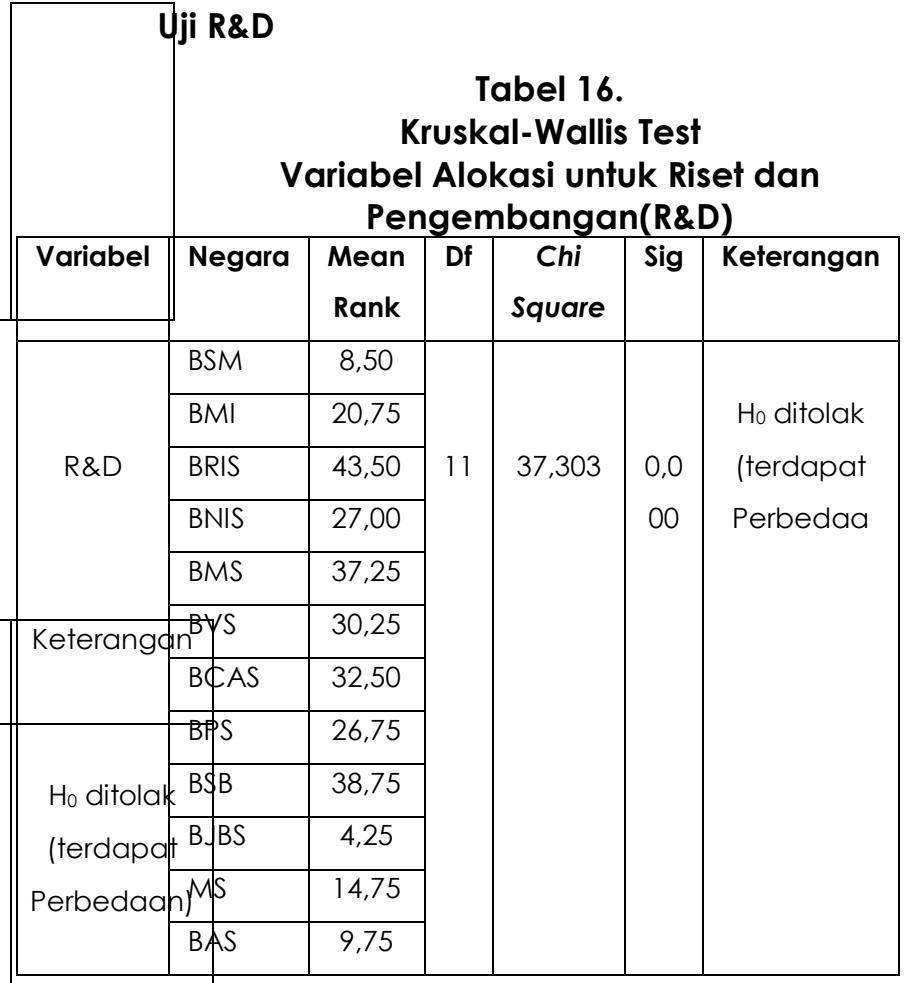

Sumber: hasil uji SPSS (data telah diolah

Pembahasan

Berdasarkan hasil uji beda menggunakan Anova dan kruskal wallis yang telah dilakukan sebelumnya, maka hasil yang didapatkan untuk semua variabel adalah sebagai berikut:

Tabel 17.

Hasil Uji Beda Semua Variabel Bank Umum Syariah di Indonesia Periode 2013-2016

\begin{tabular}{|c|c|c|}
\hline Variabel & Hasil Uji Beda & Keterangan \\
\hline MMR & $\mathrm{H}_{0}$ ditolak & Terdapat Perbedaan \\
\hline KR & $\mathrm{H}_{0}$ ditolak & Terdapat Perbedaan \\
\hline PFA & $\mathrm{H}_{0}$ ditolak & Terdapat Perbedaan \\
\hline QR & $\mathrm{H}_{0}$ ditolak & Terdapat Perbedaan \\
\hline ZR & $\mathrm{H}_{0}$ ditolak & Terdapat Perbedaan \\
\hline RFS & $\mathrm{H}_{0}$ ditolak & Terdapat Perbedaan \\
\hline CSR & $\mathrm{H}_{0}$ diterima & Tidak Terdapat Perbedaan \\
\hline KSM & $\mathrm{H}_{0}$ ditolak & Terdapat Perbedaan \\
\hline KM & $\mathrm{H}_{0}$ ditolak & Terdapat Perbedaan \\
\hline KI & $\mathrm{H}_{0}$ ditolak & Terdapat Perbedaan \\
\hline KPW & $\mathrm{H}_{0}$ ditolak & Terdapat Perbedaan \\
\hline KPP & $\mathrm{H}_{0}$ ditolak & Terdapat Perbedaan \\
\hline PKSR & $\mathrm{H}_{0}$ ditolak & Terdapat Perbedaan \\
\hline
\end{tabular}


Soegiharto, et al/Jurnal Ekonomi Syariah Teori dan Terapan Vol. 6 No. 1 Januari 2019: 42-58; PERBANDINGAN CORPORATE SOCIAL PERFORMANCE PADA BANK UMUM SYARIAH DI INDONESIA PERIODE 2013-2016 (STUDI PADA BSM, BMI, BRIS, BNIS, BMS, BVS, BCAS, BPS, BSB, BJBS, MS, DAN BAS)

\begin{tabular}{|c|c|c|}
\hline R\&D & Ho ditolak $_{1}$ Terdapat Perbedaan \\
\hline
\end{tabular}

Sumber: hasil uji SPSS (data telah diolah)

\section{MMR}

Hasil uji Kruskal Wallis yang telah dilakukan, dapat dinyatakan bahwa dari keduabelas Bank Syariah dinyatakan terdapat perbedaan Kinerja Sosial dari segi rasio MMR karena memiliki nilai signifikansi sebesar 0,000<0,05 dan chisquare sebesar 38,959>19,68 (nilai Tabel). Perbedaan rasio MMR pada Bank Umum Syariah di Indonesia terletak pada total pembiayaan mudharabah dan musyarakah yang dimiliki masing-masing bank. Bahkan sebagian bank tidak melakukan pembiayaan berbasis bagi hasil, tetapi beberapa bank lainnya mengalami peningkatan secara stabil. Dapat disimpulkan bahwa semakin tinggi rasio ini membuktikan Bank Syariah mampu melaksanakan fungsi intermediasi sesuai dengan syariat Islam karena menjauhi unsur riba.

$A R$

Hasil uji Kruskal Wallis yang telah dilakukan, dapat dinyatakan bahwa dari keduabelas Bank Syariah dinyatakan terdapat perbedaan Kinerja Sosial dari segi rasio AR karena memiliki nilai signifikansi sebesar 0,001<0,05 dan chisquare sebesar 32,979>19,68 (nilai Tabel). Perbedaan rasio AR pada Bank Umum Syariah di Indonesia terletak pada besarnya jumlah dana pihak ketiga yang dimiliki masing-masing bank. Dapat disimpulkan bahwa semakin tinggi rasio ini membuktikan Bank Syariah mampu mendorong masyarakat dalam berinvestasi cukup baik sehingga dana investasi bisa berikan secara rata pada sektor riil.

KPJP

Hasil uji Kruskal Wallis yang telah dilakukan, dapat dinyatakan bahwa dari keduabelas Bank Syariah dinyatakan terdapat perbedaan Kinerja Sosial dari segi rasio KPJP karena memiliki nilai signifikansi sebesar 0,000<0,05 dan chisquare sebesar 35,691>19,68 (nilai Tabel). Perbedaan rasio KPJP pada Bank Umum Syariah di Indonesia terletak pada pembiayaan diatas 5 tahun yang dimiliki masing-masing bank. Sebagian bank bahkan tidak memiliki pembiayaan jangka panjang. Dapat disimpulkan bahwa beberapa Bank Syariah di Indonesia perlu meningkatkan pembiayaan jangka panjang agar mendapatkan manfaat jangka panjang juga.

PFA

Hasil uji ANOVA yang telah dilakukan, dapat dinyatakan bahwa dari keduabelas Bank Syariah dinyatakan terdapat perbedaan Kinerja Sosial dari segi rasio PFA karena memiliki nilai signifikansi sebesar $0,000<0,05$ dan $F$ Tabel sebesar 6,494>2,07 (nilai Tabel). Perbedaan rasio PFA pada Bank Umum Syariah di Indonesia terletak pada jumlah deposito dan obligasi mudharabah yang dimiliki masing-masing bank. Dapat disimpulkan bahwa beberapa Bank Syariah di Indonesia perlu meningkatkan deposito dan obligasi mudharabah, karena semakin besar rasio PFA maka 
Soegiharto, et al/Jurnal Ekonomi Syariah Teori dan Terapan Vol. 6 No. 1 Januari 2019: 42-58; PERBANDINGAN CORPORATE SOCIAL PERFORMANCE PADA BANK UMUM SYARIAH DI INDONESIA PERIODE 2013-2016 (STUDI PADA BSM, BMI, BRIS, BNIS, BMS, BVS, BCAS, BPS, BSB, BJBS, MS, DAN BAS)

bank sudah cukup baik dalam mendorong masyarakat berinvestasi jangka panjang.

$Q R$

Hasil uji Kruskal Wallis yang telah dilakukan, dapat dinyatakan bahwa dari keduabelas Bank Syariah dinyatakan terdapat perbedaan Kinerja Sosial dari segi rasio $Q R$ karena memiliki nilai signifikansi sebesar 0,000<0,05 dan chisquare sebesar 39,979>19,68 (nilai Tabel). Perbedaan rasio QR pada Bank Umum Syariah dikarenakan masih minimnya pembiayaan qardh yang diberikan bank. Hal ini disebabkan pembiayaan ini tidak menggunakan jaminan sehingga mempunyai tingkat risiko yang tinggi. Penelitian ini tidak mendukung penelitian terdahulu, Lestari (2015) bahwa tidak terdapat perbedaan dalam rasio $Q R$ pada Bank Umum Syariah. Dapat disimpulkan bahwa beberapa Bank Syariah di Indonesia perlu meningkatkan pembiayaan qardh, karena semakin besar rasio QR maka bank sudah melakukan salah satu fungsi sosialnya dengan cukup baik.

\section{ZR}

Hasil uji Kruskal Wallis yang telah dilakukan, dapat dinyatakan bahwa dari keduabelas Bank Syariah dinyatakan terdapat perbedaan Kinerja Sosial dari segi rasio ZR karena memiliki nilai signifikansi sebesar $0,000<0,05$ dan chi-square sebesar $39,123>19,68$ (nilai Tabel). Perbedaan rasio ZR pada Bank Umum Syariah di Indonesia yaitu adanya sebagian bank yang tidak membayarkan zakat sesuai ketentuan. Penelitian ini tidak mendukung penelitian sebelumnya, Lestari (2015) bahwa tidak terdapat perbedaan pada rasio ZR. Dapat disimpulkan bahwa beberapa Bank Syariah di Indonesia belum menjalankan operasional sesuai dengan prinsip syariah terkait zakat

RFS

Hasil uji Kruskal Wallis yang telah dilakukan, dapat dinyatakan bahwa dari keduabelas Bank Syariah dinyatakan terdapat perbedaan Kinerja Sosial dari segi rasio RFS karena memiliki nilai signifikansi sebesar $0,000<0,05$ dan chi-square sebesar 40,040>19,68 (nilai Tabel). Perbedaan rasio RFS pada Bank Umum Syariah di Indonesia terletak pada pembiayaan qardh dan pembayaran zakat dimiliki masing-masing bank, bahkan sebagian bank tidak memiliki kedua komponen. Dapat disimpulkan bahwa fungsi sosial bank syariah masih kurang.

\section{CSR}

Hasil uji ANOVA yang telah dilakukan, dapat dinyatakan bahwa dari keduabelas Bank Syariah dinyatakan tidak terdapat perbedaan Kinerja Sosial dari segi rasio CSR karena memiliki nilai signifikansi sebesar 0,084>0,05 dan F Tabel sebesar 1,832<2,07 (nilai Tabel). Pada rasio CSR di Bank Umum Syariah memiliki jumlah dana untuk promosi yang hampir sama besar. Dapat disimpulkan bahwa semua bank cukup baik dalam menyediakan dana untuk keperluan promosi.

KSM

Hasil uji Kruskal Wallis yang telah dilakukan, dapat dinyatakan bahwa dari keduabelas Bank Syariah dinyatakan terdapat perbedaan Kinerja Sosial dari segi rasio KSM karena memiliki nilai signifikansi sebesar $0,039<0,05$ dan chi-square sebesar 20,536>19,68 (nilai Tabel). Perbedaan rasio KSM pada Bank Umum Syariah di Indonesia terletak pada laba setelah pajak yang dimiliki masingmasing bank. Sebagian bank tidak memiliki 
Soegiharto, et al/Jurnal Ekonomi Syariah Teori dan Terapan Vol. 6 No. 1 Januari 2019: 42-58; PERBANDINGAN CORPORATE SOCIAL PERFORMANCE PADA BANK UMUM SYARIAH DI INDONESIA PERIODE 2013-2016 (STUDI PADA BSM, BMI, BRIS, BNIS, BMS, BVS, BCAS, BPS, BSB, BJBS, MS, DAN BAS)

laba ditahan yang konsisten tiap tahun nya. Semakin besar rasio ini menandakan besarnya kontribusi bank dalam mensejahterakan shahibul maal.

KM

Hasil uji Kruskal Wallis yang telah dilakukan, dapat dinyatakan bahwa dari keduabelas Bank Syariah dinyatakan terdapat perbedaan Kinerja Sosial dari segi rasio $\mathrm{KM}$ karena memiliki nilai signifikansi sebesar 0,001<0,05 dan chisquare sebesar 31,871>19,68 (nilai Tabel). Perbedaan rasio KM pada Bank Umum Syariah di Indonesia terletak pada biaya gaji dan tunjangan yang diberikan masing-masing bank. Setiap bank memiliki ketentuan tersendiri perihal tunjangan apa saja yang diberikan. Dapat disimpulkan bahwa semakin besar rasio ini menunjukkan pertanggung jawaban bank terhadap kesejahteraan pegawai baik.

KI

Hasil uji Kruskal Wallis yang telah dilakukan, dapat dinyatakan bahwa dari keduabelas Bank Syariah dinyatakan terdapat perbedaan Kinerja Sosial dari segi rasio KI karena memiliki nilai signifikansi sebesar 0,004<0,05 dan chi-square sebesar 27,376>19,68 (nilai Tabel). Perbedaan rasio KI pada Bank Umum Syariah di Indonesia terletak pada hak pihak ketiga atas bagi hasil yang dimiliki masing-masing bank. Sebagian bank bahkan tidak memiliki atau tidak mempublikasikan hak pihak ketiga atas bagi hasil tersebut. Dapat disimpulkan bahwa semakin besar rasio ini menunjukkan tanggung jawab bank terhadap investor sangat baik.
KPW

Hasil uji Kruskal Wallis yang telah dilakukan, dapat dinyatakan bahwa dari keduabelas Bank Syariah dinyatakan terdapat perbedaan Kinerja Sosial dari segi rasio KPW karena memiliki nilai signifikansi sebesar $0,000<0,05$ dan chisquare sebesar 40,179>19,68 (nilai Tabel). Perbedaan rasio KPW pada Bank Umum Syariah di Indonesia terletak pada bonus rekening wadiah yang dimiliki masingmasing bank. Bonus rekening wadiah tidak dapat diperjanjiakan diawal akad. Dapat disimpulkan bahwa semakin besar rasio ini menunjukkan kesejahteraan pemegang wadiah baik.

KPP

Hasil uji Kruskal Wallis yang telah dilakukan, dapat dinyatakan bahwa dari keduabelas Bank Syariah dinyatakan terdapat perbedaan Kinerja Sosial dari segi rasio KPP karena memiliki nilai signifikansi sebesar 0,007<0,05 dan chisquare sebesar 25,807>19,68 (nilai Tabel). Perbedaan rasio KPP pada Bank Umum Syariah di Indonesia terletak pada besar nya pajak yang dibayarkan masingmasing bank. Setiap bank punya kewajiban sendiri dalam pembayaran pajak apa saja yang harus di bayarkan Dapat disimpulkan bahwa semakin besar rasio ini menunjukkan tanggung jawab bank dalam pembayaran pajak sangat baik.

PKSR

Hasil uji Kruskal Wallis yang telah dilakukan, dapat dinyatakan bahwa dari keduabelas Bank Syariah dinyatakan 
Soegiharto, et al/Jurnal Ekonomi Syariah Teori dan Terapan Vol. 6 No. 1 Januari 2019: 42-58; PERBANDINGAN CORPORATE SOCIAL PERFORMANCE PADA BANK UMUM SYARIAH DI INDONESIA PERIODE 2013-2016 (STUDI PADA BSM, BMI, BRIS, BNIS, BMS, BVS, BCAS, BPS, BSB, BJBS, MS, DAN BAS)

terdapat perbedaan Kinerja Sosial dari segi rasio PKSR karena memiliki nilai signifikansi sebesar 0,001<0,05 dan chisquare sebesar 32,270>19,68 (nilai Tabel). Perbedaan rasio PKSR pada Bank Umum Syariah di Indonesia terletak pada biaya pendidikan dan pelatihan yang dimiliki masing-masing bank. Sebagian bank bahkan tidak mengeluarkan biaya tersebut. Dapat disimpulkan bahwa beberapa Bank Syariah di Indonesia perlu meningkatkan biaya pelatihan dan pendidikan agar mendapatkan sumber daya yang berkualitas.

R\&D

Hasil uji Kruskal Wallis yang telah dilakukan, dapat dinyatakan bahwa dari keduabelas Bank Syariah dinyatakan terdapat perbedaan Kinerja Sosial dari segi rasio R\&D karena memiliki nilai signifikansi sebesar 0,000<0,05 dan chisquare sebesar 37,303>19,68 (nilai Tabel). Perbedaan rasio R\&D pada Bank Umum Syariah di Indonesia terletak pada biaya riset dan pengembangan yang dimiliki masing-masing bank. Sebagian bank bahkan hanya memiliki dana untuk pemeliharaan dan perbaikan. Dapat disimpulkan bahwa beberapa Bank Syariah di Indonesia perlu meningkatkan pembiayaan riset dan pengembangan agar bank selalu mengikuti perkembangan jaman.

\section{SIMPULAN \\ Berdasarkan hasil penelitian dan juga pembahasan pada bab sebelumnya, maka kesimpulan yang}

dapat diambil adalah berdasarkan uji beda menggunakan ANOVA dan KruskalWallis pada Bank Syariah dinyatakan terdapat yang perbedaan signifikan pada komponen:

1. KPE rasio $M M R, A R, K P J P, P F A$

2. KKM rasio $Q R, Z R, R F S$,

3. KUS rasio $K S M, K M, K I, K P W, K P P$,

4. PKSR rasio PKSR, R\&D.

Sedangkan pada komponen KKM rasio Pelaksaan Fungsi Edukasi dinyatakan tidakterdapat perbedaan yang signifikan.

\section{DAFTAR PUSTAKA}

Al-Jawziyyah, I.Q. 1995. I'lam alMuwaqqi'in. Kaherah

Alma, Buchari dan Donni Juni Priansa. 2009. Manajamen Bisnis Syariah. Bandung: Alfabet

Anshori, Muslich dan Iswati. 2009. Metodologi Penelitian Kuantitatif. Surabaya: Airlangga University Press.

Antonio, M.Syafi'i. 2001. Bank Syariah, Dari Teori Ke Praktik. Jakarta: Gema Insani

Dendawijaya, Lukman. 2009. Manajemen Perbankan.Bogor:

Ghalia Indonesia.

Indriantoro, dkk. 2002. Metodologi Penelitian Edisi 1. Yogyakarta: BPFE Yogyakarta

Kasmir. 2015. Analisis Laporan Kevangan. Jakarta: PT Raja Grafindo Persada.

Lestari, Putri Catur Ayu. 2015. Analisis Perbandingan Kinerja Fungsi Bisnis dan Fungsi Sosial pada Bank Muamalat Indonesia, Bank Syariah Mandiri, BRI Syariah dan Bank 
Soegiharto, et al/Jurnal Ekonomi Syariah Teori dan Terapan Vol. 6 No. 1 Januari 2019: 42-58;

Mega Syariah Periode 2009-2013.

Surabaya: Universitas Airlangga

Lind, Douglas A, dkk. 2013. Teknik-teknik

Statistika dalam Bisnis dan

EkonomiMenggunakan Kelompok

Data Global Edisi 13 Buku 1.

Jakarta: Salemba Empat

Muhammad. 2005. Manaemen Dana Bank

Syariah. Yogyakarta: EKONISIA.

Rahman,A.R.A. dan Goddard, A. 1998. An

Interpretive Inquiry of Accounting

Practices in Religious Organisations.

Financial Accountability and

Management Vol 14. No. 3. Hal

184-190

Rivai, Veithzal dan Arviyan Arifin. 2010.

Islamic Banking: Sebuah Teori,

Konsep, dan Aplikasi. Jakarta: Bumi

Aksara.

Setiawan, Azis Budi. 2009. Kesehatan

Finansial dan Kinerja Sosial Bank

Syariah di Indonesia. Seminar

Ilmiah Kerjasama Magister Bisnis

Keuangan Islam. Jakarta:

Universitas Paramadina

Sugiyono. 2012. Metode Penelitian

Kuantitatif, Kualitatif, dan R\&D.

Cetakan ke-17. Bandung: CV

Alfabeta

Susanto, A.B. 2009. Reputation-Driven

Corporate Social Responsibility:

Pendekatan Strategic

Management dalam CSR. Jakarta:

Esensi Group Erlangga. 